\title{
TUNTEET JA VUOROVAIKUTUS
}

Psykologia on tieteenaloista se, jonka omimmaksi alaksi tunteet mielletään. Mutta senkään piirissä ei olla yksimielisiä siitä, miten tunne (emootio) olisi määriteltävä ja onko sen perusta viime kädessä biologisfysiologinen, tajunnallinen vai sosiaalinen. Tunteet ovat parin viimeisen vuosikymmenen aikana alkaneet herättää laajempaa kiinnostusta myös monilla muilla tieteenaloilla, kuten moraalifilosofiassa, kielentutkimuksessa ja viestinnän tutkimuksessa. Tässä artikkelissa tunteita tarkastellaan empiirisen aineiston avulla resursseina vuorovaikutustilanteissa.

\section{SANNA VEHVILÄINEN}

$\mathrm{J}$ uha Varila (1999) pohti viitisen vuotta sitten tunteiden poissaoloa aikuiskasvatuksen tutkimusagendasta todeten, että tieteenalamme ihmiskuva on ollut ohut. Edelleen vaikuttaa, että tunteiden rooli aikuiskasvatusta tai aikuisen oppimista koskevissa keskusteluissa on lähinnä taustatekijän (tosin ks. Forsberg 2002; Varila \& Ikonen-Varila 2003; Isokorpi 2003). Tunteet ymmärretään lähinnä oppimista edistävänä tai estävänä ilmapiiri- tai motivaatiotekijänä, ei niinkään systemaattisesti teoretisoituna osana aikuiskasvatuksen ilmiöitä. Tunteet eivät juuri tule tarkastelun kohteeksi oppimistilanteita tai kasvua konstituoivana tekijänä sen paremmin kuin oppimisen kohteenakaan. Aikuiskasvatustiede on toistaiseksi myös paljolti sivuuttanut empiirisinä tutkimuskohteina sellaiset käytännöt, joissa keskitytään käsittelemään tunteita privaatisti (arkielämän ihmissuhteet) tai institutionaalisesti (terapia tai "itsen kehittämisen markkinat"). Sosiaalinen vuorovaikutus on perustava ilmiökenttä, jonka kautta aikuiskasvatuksen ilmiöt todellistuvat. Myös vuorovaikutus saa aikuiskasvatuksessa usein "mausteen" tai taustamuuttujan roolin. Vuorovaikutus voidaan kuitenkin ymmärtää kaikkea sosiaalista toimintaa osaltaan konstituoivaksi ilmiöalueeksi. Näin ajatellaan erityisesti etnometodologian ja keskustelunanalyysin tutkimusperinteiden piirissä (esim. Heritage 1996; ks. myös Goffman 1981 ; 1986), mutta tällainen ajatus motivoi myös monia muita sosiaalisesta konstruktionismista ponnistavia tutkimussuuntauksia.

Aikuiskasvatuksen kannalta onkin hedelmällistä pohtia, kuinka tunteet osaltaan konstituoivat sosiaalisia tilanteita, jotka miellämme oppi- mista tai kasvua edesauttaviksi tai siihen tähtääviksi. Tässä artikkelissa tarkastelen asiaa empiiristen tutkimusesimerkkien avulla, tarkastellen tunteita sosiaalisten tilanteiden resurssina. Esimerkit ovat peräisin tutkimuksistani psykoterapian ja psykokulttuurisen aikuiskasvatuksen piiristä (ks. Vehviläinen 1996a; 1996b; 2002; 2003) ja niiden analysoimisessa olen soveltanut etnometodologiaa (psykodraama) sekä keskuste-

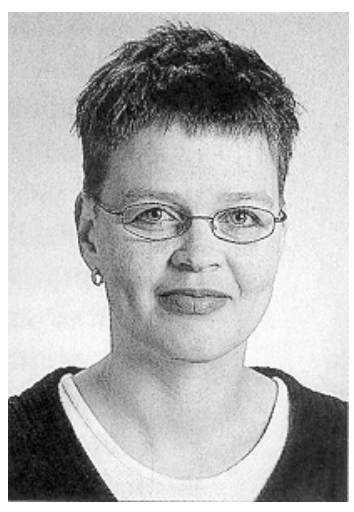

Sanna Vehviläinen lunanalyysia (psykoanalyysi).

Etnometodogia tarkastelee empiirisesti, havainnointi- tai nauhoitehavaintoihin perustuen, sosiaalisen toiminnan rakentumisen eri keinoja, toimijoiden tapoja rakentaa tilanteen jaettu merkitys erilaisilla käytännöillä (Garfinkel 1967; Heritage 1996). Keskustelunanalyysi puolestaan tutkii etnometodologisessa hengessä nauhoitteiden pohjalta sitä, miten keskustelun rakenteita käytetään tuottamaan erityisiä institutionaalisia (esim. ammattilais-asiakas) kohtaamisia (esim. Drew \& Heritage 1992). ${ }^{1}$

\section{ITSEN KEHITTÄMISEN MARKKINAT TUTKIMUSKOHTEENA}

"Itsen kehittämisen" markkinoilla tarjontaa ovat kurssit, luennot ja tapahtumat, kirjallisuus, keskusteluohjelmat ynnä muut kulttuurimuodot, jotka perustuvat tieteellisiin, kvasitieteellisiin tai 
joskus uskonnollisiin aineksiin ja joissa yksilön tunteet, olot ja kasvu ovat huomion tai yhteistoiminnan kohteena. Tunteet ja oma kokemus ovat lähtökohtana ja oppimisen kontekstina. Tunteet tai olot voivat myös olla näissä oppimistilanteissa oppimisen tai muutoksen merkki. Tutkimani psykodraamaviikonlopun ensikertalainen osanottaja tiivistää ennakkomielikuvaansa psykodraamasta: "maataan lattialla ja huudetaan että tunteita tulis esille", kun taas toinen, kokeneempi ryhmäläinen näkee "välineen asioiden ratkomiseen" (Vehviläinen 1996, 52).

Tällaista minän ja tunteiden käsittelyyn keskittyvää toimintaa ja siihen liittyviä ajattelutapoja voidaan tarkastella myös diskursseina, kehystävinä ja oikeuttavina säännöstöinä, jonka nojalla erilaiset toiminnat ja lausumat tulevat ymmärrettäväksi: jonka nojalla puhe tunteista tai tunteiden tunnistaminen saa mielekkyytensä. Kykymme käyttää tällaista diskurssia voi vaihdella, mutta kokonaan pakoon sitä tuskin kulttuuripiirissämme pääsemme. Tällainen diskurssi edellyttää, että yksilö (a) osaa tunnistaa ja nimetä omia tunteitaan sosiaalisesti ymmärrettävillä tavoilla, (b) luottaa omiin tunteisiinsa tiennäyttäjänä, sisäisenä osoittimena siitä, mikä on "oikein" tai "mitä juuri minä tarvitsen" (Taylor 1995), (c) kykenee näyttämään tunteensa muille ja itselle, ts. on rehellinen; sekä (d) osaa käsitellä ja tulkita toisten ihmisten tunteita ja ottaa ne huomioon sosiaalisessa elämässä. Tällaisen diskurssin tapaamme paitsi koulutuksen ja terapian piiristä, myös naisten- ja perhelehdistä, muista kulttuurituotteista ja arkikeskusteluista.

Sosiologiassa ja filosofiassa on pitkä perinne tarkastella tällaisia "tunnekäytänteitä" (jälki)modernin kulttuurin osana, kulttuurimuotoina, käytänteinä sekä niihin kytkeytyvinä moraliteetteina ja valtasuhteina (esim. Lasch 1980; Sennett 1986; Giddens 1991; Taylor 1995, Furedi 2004). Tällaisissa näkemyksissä suhteellistetaan käsitystä autenttisesta yksilöstä sekä identiteetin tuottamisen tavoista. Minän käsittelyyn keskittyvää toimintaa on tarkasteltu myös rituaalisena tai "pyhittävänä” toimintana maallistuneessa ja yhteisöllisyyden perustat kadottaneessa ajassa (vrt. Heiskala 1991). Tältä pohjalta esimerkiksi Kivivuori on kutsunut tätä toimintojen ryvästä "psykokulttuuriksi" (Kivivuori 1992, vrt. Kivivuori 1999), ja esittänyt moralisoivia näkemyksiä narsistisesta minän palvonnasta. Aika ajoin on muistutettu, että tällaiseen kulttuuriin liitty- vät toimintatavat tai pedagogiikat voivat olla paitsi tukevia ja emansipoivia, myös yhteisöllisyydestä poissulkevia (Bernstein 1977; Broady 1991). Tätä keskustelua käydään myös toistuvasti julkisessa sanassa ja mielipidekirjoittelussa etenkin työvoimakoulutuksen yhteydessä. On esitetty, että kaikenlainen minuuden ylösrakennus voi työvoimakoulutukseen joutuneen työttömän näkökulmasta tulla tulkituksi myös patologisoivana terapointina tai huuhaana. Kriittisiä äänenpainoja on esiintynyt myös tutkimuksessa, jossa minää työstävä koulutusta tarkastellaan myös hallintakäytäntönä (Vehviläinen 1997; Silvennoinen 2002).

\section{TUNTEET JA KIELENKÄYTTÖ - KUMPI HEIJASTAA KUMPAA?}

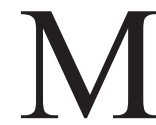
iten tunnetta sitten voisi lähestyä tutkimuksessa? Psykologiset määritelmät ovat usein arkikokemustammekin lähellä: tunteisiin (emotion) liittyy sekä mielellinen että kehollinen tuntemus tai tila (feeling), jonka jäsentyy myös ajallisesti, kestonsa suhteen. Tällöin emootiolla on myös sosiaalinen sisältö ja tulkinta sekä hyväksi tai huonoksi määrittyvä lataus. Tunnetila, jolle on erotettavissa kohde ja rajattu kesto, voidaan myös erottaa mielialasta (mood), joka on kestoltaan pidempi eikä kohteinen. (Frijda 2000; Varila 1999, 68-70.)

Psykologia lienee tieteenaloista se, jonka omimmaksi alaksi tunteet mielletään, mutta senkään piirissä ei olla yksimielisiä siitä, miten tunne (t. emootio) olisi määriteltävä ja onko sen perusta viime kädessä biologis-fysiologinen, tajunnallinen vai sosiaalinen (Berscheid 1990; Frijda 2000). Psykologisen tunnetutkimuksen näkökulmasta on olemassa joukko ilmiöitä, jotka eivät ole selitettävissä ilman viittausta yksilöiden "sisäisiin tiloihin”. Tällaisia ilmiöitä ovat mm. tunteisiin liittyvä ajallisesti jäsentyvä kokemus, joka syntyy responssina johonkin tapahtumaan (ulkoiseen tai sisäiseen), tunteen valenssi (hyvä tai paha), fysiologiset muutokset ja ilmeet. Tunteiden ymmärtäminen yksilön tiloina liittyy myös siihen, että ne eivät ole tahdonalaisesti säädeltäviä, ja että tämän nojalla meillä on myös erottelu aitojen tai teeskenneltyjen tunteiden välillä. Psykologia ottaa tehtäväkseen analysoida näitä tiloja ja selittää niitä ja niihin vaikuttavia tekijöitä yksilötasolla (Frijda 2000, 59-60).

Tunteet ovat parin viimeisen vuosikymmenen 
aikana alkaneet herättää laajempaa kiinnostusta myös monilla muilla tieteenaloilla. Muun muassa moraalifilosofian (Nussbaum 2003), kielentutkimuksen (Ochs \& Schieffelin 1989; Besnier 1990) ja viestinnän tutkimuksen piirissä (Planalp 1999) piirissä hahmotetaan näkemyksiä, joissa tunteet ymmärretään keskeisenä sosiaalisen tietämisen ja orientoitumisen tapana - tapana suuntautua muihin ihmisiin ja ympäristöön, ymmärtää ja arvottaa ympäristöämme sekä jäsentää ja merkityksellistää sosiaalista toimintaa.

Kielentutkijat Elinor Ochs ja Bambi Schieffelin (1989) ehdottavat, että tunteita tai laajemmin affektisuutta voisi tarkastella eräänä perustavana kielenkäyttöä jäsentävänä piirteenä. Suuntaudumme vuorovaikutuksessa jatkuvasti ja kattavasti tunneviesteihin; mielialan, asenteen tai tunnetilan (eli affektisuuden) merkkeihin, etsimme niitä ja jäsennämme omaa kielenkäyttöämme näiden viestien ohjaamana. Niinpä tunne voi toimia vuorovaikutuksen tutkijallekin analyyttisena näkökulmana. (vrt. Peräkylä 2004, 9-15).

Kielenkäytön ja tunteiden välisen suhteen tarkastelussa voidaan valita kaksi hyvin erilaista suuntaa (White 2000, 30-31; Bamberg 1997, 298-312). Ensinnä voidaan ajatella, että ihmisillä on tunteita koettuina ja määräävinä sisäisinä tiloina, jotka vaikuttavat ja värittävät tapaa jolla kieltä käytetään. Näin ensisijaistetaan tunnetila tarkastelun kohteena ja katsotaan kielenkäytön piirteiden heijastavan tunteiden todellisuutta. Tällainen lähestymistapa on esimerkiksi Lahden (2001) tutkimuksessa transferenssi-ilmiöstä (tunteensiirrosta) ammatinvalinnanohjauksessa.

Asetelma voidaan kääntää myös toisinpäin ja ottaa lähtökohdaksi kielenkäyttö. Tällöin tunteita tarkastellaan kielenkäytön säännönmukaisuuksien "lävitse" esitettynä sosiaalisena resurssina. Tässä näkökulmassa ei kielletä tunteita yksilön kokemuksessa, mutta todetaan tunteiden ja niiden esittämisen sosiaalinen ja kulttuurinen järjestyneisyys ja halutaan tarkastella tätä järjestyneisyyttä. Lähtökohdat voivat olla semanttisia, jolloin lähtökohtana ovat tietyn kielen tarjoamat tunteisiin liittyvät merkityskategoriat tai kulttuuriset mallit tai skriptit joiden avulla tunteet jäsentyvät sosiaalisesti (White 2000, 37-39, Goddard \& Wierzbicka 1997). Kun taas tarkastellaan tunteisiin liittyvien merkitysten rakentumista arkielämän kohtaamisissa ja kielenkäytössä, kyse on diskursiivisesta näkökulmasta (White 2000, 39-43, Bamberg 1997; Edwards 1997; 1999;
Harré \& Parrott 1996; Coulter 1979; 125-139). Oma tarkasteluni perustuu juuri diskursiiviseen lukutapaan. Tarkastelen seuraavassa tunteita sosiaalisen merkityksenannon resursseina, joiden käyttöä voi havainnoida vuorovaikutuksesta tai teksteistä. Sidon tunteen vuorovaikutustilanteisiin, niiden erityispiirteisiin, erityisesti toimijoiden keinoihin rakentaa ja ylläpitää tunnepitoisuutta vuorovaikutuksessa sekä käyttää tunteeseen viittaamista resurssina erilaisissa toiminnoissa. En sido tarkasteluani emootio -käsitteeseen, vaan näen tunteen kielen- ja keskusteluntutkijoiden tapaan affektisuutena.

\section{TUNTEET VUOROVAIKUTUKSESSA}

Vuorovaikutusta tarkastelevassa tutkimuksessa voidaan tunne "lukea" aineistosta kahdella tavalla. Tunne voi olla puheenalaisena, jolloin nimenomaan tunteen nimeäminen tai tunteesta puhuminen on lähtökohta analyysille. Tästä lähtökohdasta analysoin tekstini lopulla esimerkkiä 5 psykoanalyysivuorovaikutuksesta sekä psykodraamatutkimukseni otteita 3 ja 4 . Tunnetta voidaan tarkastella myös ei-puheenalaisena mutta silti vuorovaikutuksessa havaittavasti läsnäolevana. Tällöin toimijat orientoituvat havaittavasti tunteeseen, tilanteen tunnelataukseen tai toisen ihmisen mielialaan tai asennoitumiseen, vaikka eivät suoranaisesti nimeä tai kuvaa tunteitaan. Tällä tavalla tarkastelen psykodraamaesimerkkiä 2 .

Affektisuus voidaan lukea kielenkäytön piirteistä monin tavoin. Tunteen indeksejä voivat olla nauru, hymy, kasvonilmeet, asennot, eleet, äänen sävyn, korkeuden tai voimakkuuden muutokset tai sanavalinnat. Useat tällaiset piirteet ovat saaneet kielenkäytössä vakiintuneen merkityksen, osaa pidetään universaaleina (Ochs \& Schieffelin 1989; Besnier 1990). Affektisuus voi olla joidenkin rajattujen puheenvuorojen ominaisuus jossain kohtaa voi syntyä esimerkiksi "närkästystä" tai "lohduttamista". Kyse voi olla myös kestoltaan pidemmästä, kollektiivisesti jaetusta ilmapiiristä, kuten "hartaus" tuonnempana kuvaamassani psykodraamaesimerkissä.

Seuraavassa käsittelemäni esimerkit ovat peräisin tutkimuksistani psykodraaman ja psykoanalyysin vuorovaikutuksesta (ks. Vehviläinen 1996a; 1996b; 2002; 2003). Osoitan eri tapoja joilla tunne on vuorovaikutuksessa läsnä. Havainnollistan samalla kahta hieman erilaista analyy- 
sityyliä: kenttähavainnointia ja nauhoitteisiin perustuvaa vuorovaikutuksen analyysiä hyödyntävää etnometodologista analyysiä sekä vuorovaikutuksen rakenteita yksityiskohtaisemmin erittelemään keskittyvää keskustelunanalyysiä. Lopuksi pohdin yleisemmin, mitä hyötyä tunteiden tarkastelusta olisi aikuiskasvatuksen vuorovaikutuksen tutkimuksessa. (Huom. Kaikkien käsittelemieni otteiden erisnimet ovat pseudonyymejä ja muutamia muita tunnistamiseen vaikuttavia tietoja on muunneltu. Litterointikoodit esitän liitteessä 1)

\section{TUNTEET RESURSSINA VUOROVAIKUTUKSESSA}

Aluksi tarkastelen tunteita sosiaalisena resurssina (1. "etnometodina", ks. Garfinkel 1967) psykodraamassa. Kuvaus perustuu etnometodologiseen tutkimukseeni psykodraama-viikonloppukurssista (Vehviläinen 1996a). Tutkin etnografisen havainnoinnin ja vuorovaikutusanalyysin keinoin, miten psykodraamassa toimijat rakentavat toimintansa merkityksen ja luovat sen järjestyneisyyden kielen ja vuorovaikutuksen keinoilla. Käytin analyysivälineinä Goffmanin kehysanalyysiä (1986) sekä osallistujakehyksen (Goffman 1981) käsitettä, jäsenyyskategoria-analyysia (esim. Hester \& Eglin 1997) sekä joitain keskustelunanalyyttisia peruskäsitteitä (esim. Heritage 1996). Erityisesti tarkastelin sitä, kuinka rakennetaan yhteistä toimintaa, jossa kohteena on toimijoiden sisäisyys, oma minä. Ryhmässä oli 9 osallistujaa ja 2 ohjaajaa, ryhmä kokoontui ai-noastaan viikonlopun ajaksi, ja kurssia oli markkinoitu kelle tahansa mielensä tutkimisesta kiinnostuneelle. Osallistujista osa oli ensikertalaisia, osa konkareita. Tutkimus oli asetelmaltaan pienoisetnografia: ryhmä oli tuossa kokoonpanossa vain ko. viikonlopun ajan, ja tutkijana siten todistin ko. prosessin alusta loppuun. Kentän rajaus oli siis "luonnollinen", toi-mijoiden oma rajaus.

\section{Vuorovaikutuksen formaalisuus ja kollek- tiivisen affektin (tunnelman) rakentuminen}

$\mathrm{H}$ avainnointikokemuksistani eräs vahvimmista oli paitsi draamatyöskentelyn vaikuttava elämyksellisyys ja taidokkuus, myös harras tunnelma, joka syntyi draamoja purkavissa rinkikeskusteluissa ja joka muistutti joitain näkemiäni uskonnollisia tilanteita. Kokemuksena se oli hyvä. Kirjoitin: "Tuntemuksiini liittyi myös esteettinen elämys, jokainen ihminen alkoi näyttää kauniilta, täydelliseltä, kuin taideteokselta." (Vehviläinen 1996a, 62) Löysin kuvauksia tästä esteettisestä elämyksellisyydestä paitsi psykodraamakirjallisuudesta (mts. 63) myös psykodraamaviikonlopun jakamispuheenvuoroista:

\section{Esimerkki 1 [}

\section{psykodraama/jakaminen Marjalle]}

1 Jaana: mun mielest täs jutus oli kauheen kiva olla

2 mukana (se oli) lämminhenkinen (.) (noi)

3 roolit oli (semmosia) lämminhenkisiä (.)

4 semmonen hyvä ja rauhallinen olo

$5 \quad()$

6 Virpi: mul oli ihan sama (.) mun mielest siin (-)

$7 \quad$ varsinki se (.) se (-) luostari juttu oli (-)

8 aivan upee

$9 \quad($.

10 Marja: $\mathrm{mhmm}$

11 Virpi: ja mun palautu niin elävästi mieleen (.) ku

12 mä joskus oon lukenu (.) Laila Hietamiehen

13 sen Laatokka -sarjan (.) ni siinä oli se

14 Anna (.) joka oli tämmönen yrttien kasvattaja

Tutkimuksessani halusin purkaa yksinkertaistavaa näkemystä, jonka mukaan psykokulttuurin muodot ovat "nykyajan rituaaleja", uskonnon korvikkeita. Totesin ettei psykodraamatoiminta tyhjene rituaaliksi, vaikkakin jotkut sen toistuvista tilanteista rakentuvat rituaalinkaltaisiksi ja si-sältävät rituaalista hartautta (Vehviläinen 1996a; 213-215).

Halusin silti eritellä, kuinka kollektiivinen affekti - harras ja lämmin tunnelma - syntyi. Havainnoijana aistin sen selvästi ja säätelin käyttäytymistäni, jotten häiritsisi sitä istuessani nurkassa vihkoineni ja nauhureineni. Usein ihmiset kaiketi kokevat, että tilanteen ainutkertaista tunnelatausta ei voi (tai pidä) selittää tai yrittää palauttaa niin teknisiin asioihin kuin vuorovaikutuksen piirteisiin, koska se syntyy uniikista kohtaamisesta ja "henkilökemioista". Sosiaalisesti jaettu kokemus on kuitenkin aina synnytetty yhdessä toimijoiden rutiininomaisesti hallitsemilla vuorovaikutuksen keinoilla, joita voi eritellä ja vertailla. (Muutenhan se ei olisi intersubjektiivinen eli yhteisesti mielekäs sosiaalinen tilanne.) Kokemani mukaan nämä samat vuorovaikutuksen piirteet voivat hetkellisesti tuottaa vastaavan tunnelataukseltaan vahvan, liikuttavan hetken vaikkapa keskelle arkista seminaarityöskentelyä. 
Aikuiskasvatuksen kentältä löytynee useita kohtaamistyyppejä, joissa ihmiset saavat yhdessä aikaan jotain vastaavaa. Siten pidän hyödyllisenä tunnistaa empiirisesti näiden vuorovaikutuksellisten "tunnelmatekijöiden" käyttöä.

Psykodraamassa tehdään ohjatusti dramatisointeja protagonistin eli päähenkilön elämästä hänen kertomansa mukaan (psykodraamamenetelmästä mm. Moreno 1977; Kellerman 1992). Sen jälkeen niitä jaetaan ryhmässä. Erittelen seuraavassa, miten jakamistilanteen vuorovaikutusjärjestys (järjestys jota ei ole missään säännöillä julistettu, mutta jota toimijat kannattelevat joka hetki omalla toiminnallaan) synnyttää kollektiivisen tunnelman. Näytän ensin otteen jakamispuheesta, jonka jälkeen erittelen sitä.

\section{Esimerkki 2 [psykodraama/jakaminen Virpille]}

\section{1 ((tuolien siirtelyä))}

2 Noora: niille ketkä (.) ketkä ei oo aikasemmin ollu 3 psykodraamaryhmässä ni (.) näitten 4 työskentelyjen jälkeen tehdään sellasta 5 mitä sanotaan jakamiseks (.) joka on sitä 6 että (.) että ryhmän jäsenet voi omista 7 kokemuksistaan kertoa sille joka on 8 työskennelly (.) siitä mikä heidän elämäs9 sään on ollu samankaltasta tai (.) mikä (.) 10 nousi mieleen siitä mitä näki (.) ja sit ne 11 inmiset jotka on ollu rooleissa ni voi (.)voi 12 sanoa niistä rooleista (.) sisäisiä olo ja 13 (.)

14 Kauko:niin (.) mulle: (.) tässä: (.) oli (.) hyvin tuthalunnut (.) minua (.) mminä olin syntynyt niin san- niin sanottuna (.) keskosena ja (.) ja sen takia: sitten ööh (.) todella käsitin niin että: minä olin (.) ei-toivottu (.) lapsi (.) ja toinen (.) yhtymäkohta mun omaan elämääni tässä tuli tässä: (.) öö mun avioliitossani (.) jossa: nimenomaan mun vaimoni (.) aina meni tyttärensä luokse ja (.) tytär lohdutti häntä kun meillä oli ollu riita (.) ööh (.) se (.) öh inmetytti mua (.) mutta tota (.) se oli ihan ihan tämmönen (.) joka kerta tapahtuva (juttu) (.) tämä niin(.) tää tytär vielä oli (.) ottanu tän lohduttajan roolin (-) hän todella lohdutti () sitte tästä roolista (.) ööö siinä mielessä että mä olen oikeestaan ollut (.) yli viis vuotta (.) vastaavassa roolissa juuri (.) ööh tavallaan vaimon (.) öö asettamassa roolissa jossa tota: (.) hän oli (.) öö tällanen (.) mun käsittääkseni alistamisen ja väkivallan ja (.) ööh vast- tän tapasten kokemusten takia (.) ai:ka vihanen miehille koko miessuku(puolelle) ja h. (.) minä (.)
46 Marja-Leena:(siin ystävän ((yskäisee)) roolissa)

tietysti (.) sain oman (.) osani sitten (.)

() tuu - läheiseltä)

() rahdus)) pysytellä paikallaan ni tuntu et la jotenki (.) jotenki (semmoseks) asiana jajaks etteikö (nyt) aikuiset ymmmärrä et ku (.) (-) puhutella et varsinki ku mä tässä nyt itse (.) (-) (kuin) aikuiset voi käyttää tätä lasta tällä tavalla (.) (-) ko(.) $(-)$

(.) sitte mä omassa elämässäni ehkä niin (.) öö oli (.) (-) mut ehkä sit (samaten) sen alun niinkun (.) tää lapsen tunne että ei (.) et aina niinku täytyy (-) meidän permeni) niinku pieleen siinä ja että: sitte jo tenki (.) mun on täytyny olla sitte kyllä kauheen huono laps vielä kun ei mun jälkenu kauheesti niinku syyllisyyttä siitä että (.) ku mä oon ainoo laps että niinku on ollu niin pettyneitä (.) et nei oo halun ku järkeenkäypää omasta mielestä mun vanh-lapsena semmosta järkeenkäypää selitystä saanu sille et miksei (.) miksei mä oisin (kyl sit) toivonu kauheesti (-) () tällasta (.) (-) omassa elämässäni (.) (tunniin (.) oli (.) kauheen vaikee jotenki ((nauniinku monessa kohtaa ois halunnu (.) tulmitä te teette tälle lapselle (.) jotenki niinolin- olin tämmönen vanhempi ihminen (.) olla niinku noin (.) ymmärtämättömiä ja (.) vasti ois halunnu niinku (.) mukaan siihen o० (.) ei oo (.) hyväksytty tai (.) tai odotettu heeseen odotettiin poikaa (.) ja tota: (.) (se keen oo haluttu lisää lapsia (.) mä oon komä oon jotenki (.) niinku pipariks (.) pelannu tän lapsen osan että (.) et vanhemmat nu enempää .h (.) et ku en oo mitään niinmeijän perheessä ollu enempää lapsia (.)

Jakamisessa puhutaan pitkiä monologisia vuoroja, joiden välissä on pitkiä, useiden sekuntien taukoja. "Hartaus" ei synny kuitenkaan pelkästään siitä. Kyse on myös puheenvuorojen si-sällöstä, siitä, miten ne rakentuvat suhteessa toisiinsa sekä siitä, mitä niiden välisiin hiljaisuuksuuksiin attribuoidaan. ${ }^{2}$

Jakamisvuorot esitetään nk. formaalin (muodollisen) vuorovaikutusjärjestyksen puitteissa: vuorojen määrää, järjestystä ja sisältöä säädellään ja tähän säätelyyn orientoidutaan sitovana ja normatiivisena (vrt Sacks yms. 1974; vrt. Arminen 1998; Halonen 1999). Psykodraamatyöskentelyn jälkeen ryhmäläiset "jakavat protagonistille" eli kertovat vuorotellen draamaa tehdessä tai katsoessa heränneistä tuntemuksistaan ja mielikuvistaan draaman päähenkilölle. Protagonisti on 
kuuntelijana. Jokaiselle ryhmäläiselle omistetaan pääosin yksi vuoro. Vuorot voivat olla moniosaisia, käsitellä useita asioita (ks. Kaukon ja MarjaLeenan vuorot yllä). Koska niiden sisältöä tai kestoa ei säännellä, on vuoroa havittele-vien varmistuttava että edellinen on lopettanut (ks. Kaukon vuoro yllä, jossa vuoron lopetuksen mahdollistavan kohdan jälkeen vuoroon liitetään vielä "lisäyksiä".) Tiiviit siirtymät vuorosta toiseen tai päällekkäispuhunnat siirtymäkohdissa (jotka olisivat tavanomaisia ei-formaaleissa keskusteluissa; vrt. Sacks ym. 1974; Hakulinen 1997) tuottaisivat kiirehtimisen sävyn. Hyvin pitkät hiljaisuudet toimivat siis formaalin vuorovaikutusjärjestyksen säätelyvälineenä. Jokaisen ainokainen vuoro saa siten tarpeellisen rauhan.

Hiljaisuuksilla on kuitenkin muutakin merkitystä. Niiden aikana jokainen osallistuja mielletään hiljentyneenä draaman sekä sen herättämien mielikuviensa äärelle. Hiljaisuudet ovat tavallaan täynnä näitä sisäisiä kuvia, ja hiljaisuus myös kunnioittaa näitä kuvia - hieman samaan tapaan kuin uskonnollisessa, rituaalisessa vuorovaikutuksessa hiljaisuudelle voidaan attribuoida sisältöä, jossa ihmisten ajatellaan kommunikoivan jumaluuden kanssa.

Monologien lisäksi muuta keskustelua käydään vähän. Poikkeamat järjestyksestä yleensä myös "merkitään" poikkeaviksi. Jos jakamiseen aukeaa keskustelullinen kohta, sen jälkeen palataan jakamisformaattiin. Kun puheenvuorojen välillä on hyvin pitkät tauot eikä päällekkäisyyttä esiinny käytännöllisesti katsoen lainkaan (Vehviläinen 1996a, 69-74), monologiset vuorot saavat performatiivisen luonteen. Niitä kuunnellaan puhujan si-säisyydestä kumpuavana viestinä niitä ei arvioida, pureta tai kyseenalaisteta eikä esimerkiksi samaistumisen kriteereistä neuvotella. Tässä mielessä psykodraama poikkeaa monista opetustilanteista, joissa puheenvuorojen arviointiin liittyy tiedollisia arviointiperusteita. Jakamisvuoro kelpaa jakamisvuoroksi, jos se on autenttinen kokijansa oma vuoro. Merkittävää tunnelman syntymisessä on myös se, että jakamisvuoron voivat esittää myös ohjaajat. Se tuottaa hetkellisen symmetrian osallistujien välille: osallistujista on esillä se puoli, jossa he ovat kaikki tasaarvoisia, samanlaisia.

Jakamisvuoron tehtävä on siis nimenomaan olla henkilökohtainen vuoro. Voisi ajatella, että vuoron sisältö olisi tällöin täysin vapaa. Lähempi analyysi näyttää kuitenkin, miten tiivisti ne ra- kentuvat paitsi nähdyn draaman varaan, myös muiden vuorojen kuunteluun ja niiden tarjoamien ainesten hyväksikäyttöön (mts. 77, vrt. Arminen 1998). Puhujat sijoittavat vuorojen alkuun komponentteja, joissa näyttävät kuinka vuoro liittyy edellä sanottuun. Samaistumista kuvaava vuoro rakennetaan niin, että sekä mainitaan samanlaisuuden "aste" (esimerkki 2, rivit 14-16; 2122; 61-62) että kuvataan itse kokemus, kumpikaan ei esiinny yksinään. Tarpeellista on siis sekä kertoa oma asia että esittää se edeltävästä kumpuavana.

Jaettu affekti jakamisessa syntyy sekä vuorottelujärjestyksen että vuorojen muotoilun kautta: 1) Vuorovaikutuksen formaali järjestys ja sen hallinta mm. päällekkäispuheen puuttumisen sekä hiljaisuuden avulla tuottaa monologivuoroille performatiivisen luonteen. 2) Vuorojen sisältö taas rakentaa näkyville tilanteen psykokulttuurisen luonteen: samaistutaan protagonistiin ja toisiin ryhmäläisiin. Jokainen paljastaa jotain itsestään, näyttää sisintään puhumalla henkilökoh-taisista tunteista ja kokemuksista. Siten yhteisyyden pohjaksi muotoutuu yksilöllisyys - jokaisen yksilön sisältä löytyvän autenttisen minän "pyhittävä" tarkastelu.

\section{Tunteet, moraalisuus ja yhteisöllisyys: tunnereaktio ja draaman moraalinen luenta}

Kuvasin edellä jakamisen tehtävää samaistumisessa: se tuottaa yhteisyyttä yksilöllisyyden kautta. Henkilökohtaiset kokemukset ja tunteet ovat valuuttaa, jota vaihtamalla jakaminen rakentaa draamakokemuksen yhteiseksi. Tunteiden näyttämisellä on jakamistilanteessa toinenkin tehtävä. Se on keino vastaanottaa ja tulkita draamaa ja rakentaa siitä moraalisia tulkintoja, joissa ihmiset ovat paljon muutakin kuin "autenttinen sisäisyytensä". Kyse on identiteettien sosiaalisten aspektien näyttämisestä ja sen myötä tilanteisen yhteisöllisyyden rakentumisesta

Vertailevassa tunnetutkimuksessa tunteet liitetään kulttuureissa tunnettuihin sosiaalisiin episodeihin ja tyypittyneisiin suhteisiin ihmisten välillä. Tunteille mielletään kulttuurisesti määrittyvä sosiaalinen "koti" (White 2000). Diskursii-visen tunnetutkimuksen piirissä on myös todettu, että tunteiden kuvaaminen (pyydettäessä) edellyttää usein olosuhteiden ja tapahtumisen kuvausta (Bamberg 1997, 219-220; vrt. Edwards 
\& Potter 1992, 142). Tarinoiden kertominen, moraali ja tunteet ovatkin saumattomasti yhteydessä toisiinsa. Esittääksemme tarinan, henkilöiden dynamiikan ja suhteemme kertomaamme, kuvaamme tai implikoimme myös asianosaisten tunteita. Kuvatessamme meille merkittäviä tapauksia ja tilanteita rakennamme kuvaukset niin, että ne tarjoavat muille mahdollisuuden päätellä, mitä "sisällämme" on, keitä me olemme - mikä on suhteemme "hyvään". Esittääksemme itsemme moraalisina tarvitsemme siis moraalisia tunteita: sosiaalisesti sopivia tunneresponsseja erilaisiin tilanteisiin.

Psykodraamojen kohtauksiin etsitään tilanteita, asetelmia sekä henkilöitä haastattelemalla protagonistia. Käsillä on joukko kategoriapareja tai -ryppäitä (vanhempi-lapsi, puoliso-puoliso, ystävykset jne.), joiden avulla jäsennetään erilaisia tarinoita. Nämä tarinat - kuten mitkä hyvänsä tarinat - käsittelevät pohjimmiltaan sitä, mikä on oikein ja väärin, mikä on hyvää elämää. Draamat rakentuvat kohtaus kohtaukselta niin, että niissä on jokin ihmisten välinen tunnelataus, tai useita (Vehviläinen 1996a, 74-77; 119-147). Kun draamaa jälkeenpäin jaetaan, oleellista on paitsi samaistuminen, myös oman heränneen tunnelatauksen käsittely. Tunne voi olla sisäinen, pakottava tila, jota on päästävä purkamaan. Diskursiivisesti tarkasteltuna se näyttäytyy myös keinona vastaanottaa tarinan moraali. Kun vastaamme draamaan moraalisilla tunteilla, tunteet kertovat siitä keitä me olemme ja mihin kuulumme. Näin voimme myös rakentaa sosiaalisiin identiteetteihin kytkeytyvien tunteiden jakamisella yhteenkuuluvuutta toisten kanssa.

Esimerkissä 2 Marja-Leena aloitti kuvaamalla tunteitaan Virpin ystävän roolissa. Vaikka hän ei varsinaisesti nimeä tunnetta, vuoron alku on nimenomaan tunnekuvaus vahvasta myötäelämisestä toisen kärsimykseen (r. 42-52), halusta rynnätä draaman lapsen avuksi. Näin puhuja asettuu voimakkaasti lapsen puolelle, erottautuu itse tarinan aikuisista ja tähdentää nähdyn moraalista sisältöä: lapselle tehtiin vääryyttä. Virpin draamassa olikin esillä hänen raskaita kokemuksiaan vanhemmistaan, ja myös muissa jakamisvuoroissa draamaa tulkittiin tarinana lapsen epäoikeudenmukaisesta ja väärästä kohtelusta (Vehviläinen 1996, 142-147). Seuraavassa toinen jakamisvuoro saman draaman äärellä:

\section{Esimerkki 3}

\section{[psykodraama/jakaminen Virpille]}

1 Jaana: (Veikon roolissa musta tuntu) (-) raukka-

2 maiselta (.) (-) (-) ti:esin jossakin (.) (-)

3 (näin) (.) näin ei saa tota Virpii kohdellah (.)

$4 \quad(-)(-)$ voi että ku mä oon raukka mut et

5 jotenki aatteli että miks toi vaimo ei sitte

6 huomaa tätä mun tilannetta

$7 \quad($.

8 kuitenki aatteli et (johonki) mun täytyy tää

9 kiukkuni purkaa ja jotenki se näyttää et (.)

10 se oli vaan se ainoo keino millä mä pystyin

11 jotenki vaikka mä tiesin että tää on kauheen

12

13 raukkamaista

()

Jaana on esittänyt Virpin isää: hän kutsuu resurssiksi kokemuksensa "Veikkona". Hän puhuu minämuodossa ristiriitaisesta tunteesta: puhuja tuntee olevansa raukkamainen mutta silti kykenemätön muuttamaan toimintaansa. Tämä roolihenkilöä koskeva tunnekuvaus sisältää neljä oleellista seikkaa: (a) arvion Veikon toiminnan tuomittavuudesta (joka tukee tarinan moraalia protagonistin kannalta), (b) jonkinlaisen Veikon suulla esitetyn vastuunoton ("tiesin ettei näin saa tehdä mutta silti tein..."; ks. Peräkylä 1990, 38), jonka nojalla vältetään kuvaamasta Veikkoa yksiulotteisen pahana, (c) toisaalta esitetään Veikko "syyntakeisena" (hän tiesi mikä olisi ollut oikein) ja siten vahvistetaan hänen vastuutaan ja (d) nimenomaan "minän" kokemuksesta käsin esitetyn vuoron. Näin tehdään tarpeettomaksi spekuloinnit siitä, miten oikea Veikko olisi mahdollisesti ajatellut. Näin vuoron legitimaatio nousee samasta lähteestä kuin muidenkin jakamisvuorojen: se on kokemuksellinen, henkilökohtainen puheenvuoro, sellaisenaan kelpaava. (Roolihenkilön suulla puhumisesta jakamisessa ks. Vehviläinen 1996b).

Seuraavassa esimerkissä puretaan edelleen Virpin draamaa ja tarinan moraalia. Tässä myös Marja esittää roolihenkilön suulla tunnekuvauksen, jossa vahvistaa moraalisen asetelman: äiti tiesi tekevänsä väärin, mutta teki silti, ja (häntä esittäneen henkilön kokemuksessa) tuntuu "raukkamaiselta ja halvalta" (r. 4-6) että hän toimi draamassa niin kuin toimi:

\section{Esimerkki 4}

\section{[psykodraama/Jakaminen Virpille]}

1 ((pitkähkö tauko))

2 Marja: ni tohon mitä Jaana sano ni () mul on sen verran kans k-musta tuntu kans se () tosi niinku semmoselta (.) raukkamaiselta ja 


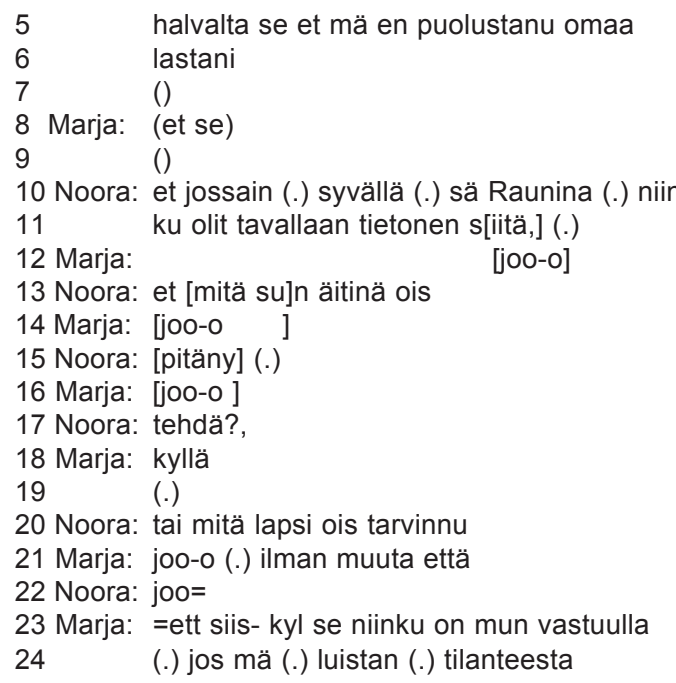

Noora-ohjaaja puuttuu jakamisen kulkuun ja avaa hetkeksi keskustelun, jossa puhuttelee Marjaa roolihenkilönä. Hän esittää päätelmän (10-13), jolla kutsuu Marjan ikään kuin todistamaan Raunin mielen sisällöistä. Kyse on tietysti Marjan moraalisesta päätelmästä. Kun se näin rakennetaan myös Raunin "tietoisuudeksi”, sisäiseksi vakuuttuneisuudeksi, moraalinen päätelmä tähdentyy. Rauni on syyntakeinen: hän on ollut "jossain syvällä tietoinen" siitä mitä hänen olisi pitänyt tehdä. Tarinan moraalia käsitellään kerroksisen tunne-resurssin avulla: mukana on Marjan tunnereaktio roolityössä sekä yhdessä konstruoitu päätelmä Raunin tunteesta ("jossain syvällä olla tietoinen siitä mitä lapsi tarvitsee" on empatian kuvausta ja siten affektista, vaikka siinäkään ei esiinny nimettyä tunnetta!).

Edellä esitetyt moraaliset tunnereaktiot tuottavat tulkinnan, jossa vastuulliset aikuiset osoittavat vuoro vuorolta myötätuntoa kaltoin kohdeltua lasta kohtaan ja tuomitsevat kaltoin kohtelevat aikuiset (tämän draaman rakentamisesta ja "luennasta" tarkemmin Vehviläinen 1996a, 119147.)

On lisäksi kiinnostavaa, että niissä jakamisvuoroissa, joissa puhuttiin omalla suulla, esitettiin lähinnä samaistumiskokemuksia, ts. kerrottiin jotain rinnakkaista omasta elämästä. Sen sijaan ne vuorot, joissa kuvattiin em. kaltaisia voimakkaita tunnereaktioita ja moraalista tuohtumusta, tulivat niiltä, jotka olivat olleet draamassa mukana. Tällä tavalla vältettiin tilanteen kannalta hajottavat tunteenilmaukset - sellaiset vuorot joissa oltaisiin järkyttyneitä mutta ulkopuolisia; kauhisteltaisiin sitä miten kamalaa jollain toisella on ollut, ilman mitään osallisuutta vastaaviin kokemuksiin.

\section{Negatiivisen tunteen käyttö 'todisteena' sisäisestä todellisuudesta}

Analysoidessani psykodraamaviikonlopun sosiaalista järjestystä havaitsin jotain samaa kuin Howard Schwartz $(1989,169)$, kun hän tutki erästä terapiaryhmää: "(P)otilaita rohkaistiin ilmaisemaan mitä heidän mielessään oli vapaasti, avoimesti ja välittämättä sopivaisuuden säännöistä. Tämä kuitenkin tarkoitti puhumista tunteista, motiiveista ja ihmissuhteista, ei jalkapallosta tai autoista - ne olivat pinnallisia, turvallisia topiikkeja, jotka peittäisivät todellisia tunteita ja pyrkimyksiä."Aidon sisäisyyden paljastaminen on siis jotain muuta kuin "tavallisen" sosiaalisen pinnan näyttämistä. Jos puhutaan liian "turvallisista" aiheista, emme voi tietää, onko henkilö todella pannut itsensä likoon. Jos puhumme jostain vaikeasta, aitoutemme on uskottavampaa.

Vaikea asia voi olla muun muassa toista ihmistä kohtaan esitetty negatiivinen tunne. Psykodraamaviikonloppukurssilla käsiteltiin useaan otteeseen erään ryhmäläisen toista kohtaan ilmaisemaa negatiivista tunnetta. Tunteenilmaisu ("ärsyttäminen") kytkettiin puhujansa henkilöhistoriaan ("kaikki miehet ärsyttävät ja siihen on syynsä’) ja hänen sisäiseen todellisuuteensa, ei tunteen kohteeseen tai hänen ominaisuuksiinsa. Kun tunteen ilmaissut ryhmäläinen toi pohdittavaksi sen, tekikö hän oikein vai väärin ilmaistessaan näitä tunteita, hänen todettiin olleen rehel-linen (sisäiselle todellisuudelleen) ja toiminta nähtiin oikeutettuna. Olen analysoinut tämän tunneilmauksen käsittelyä "rehellisyyden koodina", ts. psykokulttuuriin kuuluvana tapana käyttää negatiivisten tunteiden ilmauksia aidon si-säisyyden indeksinä 1. ilmaisijana (Vehviläinen 1996a, 9699, 114-118).

Sosiaalista toimintaamme jäsentää perustavasti ajatus, että ihmiset voivat kätkeä todelliset tunteensa ja ajatuksensa; "julkisivun" takana voi aina olla jotain piilevää. Siksipä sosiaalisen jär-jestyksen murtumia niin usein kohdellaan vuo-rovaikutuksessa osoituksina siitä millaisia ihmiset "todella" ovat (vrt. Heritage \& Atkinson 1984, 54). Psykokulttuurin piirissä tämä käytäntö saa erityi-siä muotoja. Psykokulttuurin ainekset ovat peräisin psykodynaamisesta psykologiasta: $\mathrm{mm}$. ajatus psyyken dynaamisuudesta, lapsuuden mer- 
kityksestä aikuisen psyykelle, psyyken jakautumisesta tietoiseen ja tiedostamattomaan, tunteiden torjunnasta sekä tunteiden tietoisuuteen tuomisen terapeuttisesta vaikutuksesta.

Psykoanalyysista tämä ajatus löytyykin selvempänä. Monenlaiset järjestyksen murtumat tulevat psykoanalyysissa tulkituiksi nimenomaan tiedostamattomien mielen sisältöjen ilmentyminä (esim. Frosh 2003; 84-87; Rycroft 1995, 158). Tarkastelenkin seuraavaksi, miten psykoanalyytikko käsittelee klassisessa psykoanalyysissa käyvän potilaan puheesta identifioimansa "järjestyksen murtumaa", negatiivista tunnetta.

Esimerkki kuuluu kokoelmaan otteita, joissa analyytikko ottaa puheeksi potilaan käsillä olevan tunnetilan ja kääntää siten huomion potilaaseen, pois meneillään olevasta puheenaiheesta. Olen käsitellyt tällaisia tunteen topikalisointeja eräänä psykoanalyytikon vuorovaikutuskeinona

(Vehviläinen 2002). Ilmiön fokusrivi on tummennettu otteessa. Litteraatio on edellistä tarkempi, koska tutkimus on keskustelunanalyyttinen, mutta alkuperäisestä litteraatiostani yksinkertaistettu.

\section{Esimerkki 5 [psykoanalyysi/I/32/B17]}

1 PO: Että minä (niinku)(lopu-) (.) viimeseen

2 saakka yritin jotenkin äi- äitiäni (.) äidille

3 ni todistaa et (.) et minä olisin rakastamisen

4 arvonen.

$5 \quad()$

6 PO: Et niinku mä en ois (.) ollu koskaan oikeen

7 varma siitä.

$8 \quad()$

9 AN: Nii:h.

$10 \quad()$

11 AN: .hhh Ja kylhän sinul oli syytä (.) epäillä sitä.

12 (.)

13 PO: Nii enhän mä sitä tietosesti epäilly (.) khm

14 mhh ei se ollu ehh ei se ollu ajatuksena

15 sillon koskaan mulla. (.) e- Mut minä ajatte-

lin

16 () itseäni (.) ja tekemisiäni niin siin oli se (.)

17 (apua) et minä aina yritin ja yritin (.) näyttää

18 et kuinka () hyvä minä kuitenkin olen.

\section{9 kryhhmm}

20 (.)

$21 \mathrm{AN}:$.mhhh Se on sama asia mitä sinä oot mietti22 ny paljon täällä suhteessa minuun.

$23 \quad($.

24 PO: Mit- (si o- -su-) suhteessa sinuunko.

$25 \quad($.

26 AN: (Niin ku) sinul on aina tarve (.) osottaa

27 minulle et sinä olet hyvä.

28 (.)
29 PO: Hy[vä en mä tarkota nyt ku minä sanon

30 h:yvä niin sillä

$31 \mathrm{AN}: \quad[(\mathrm{mh})$

32 PO: tavalla .hhh eee (.) m: hyvä inminen () täm-

33 mönen puolipyhimys.

$34 \quad$ (.)

35 AN: .mthhh Tuota: se on jännä kuinka sinä

36 pelkäät,

$37 \quad$ (.)

38 PO: Ei mut ku mä: mä haluun vaan selventää sen

39 et ku minä äidilleni .hhh et et hänelle minä

40 halusin (.) minä halusin et hän hän huomaa

41 et kuinka .hhh kuinka ahkera minä olen rei-

42 pas ja kuinka hyvä::, .hhh ja sit tämmösiä

43 ihan kä:ytännön asioita.

44 AN: Kuinka ilonen sinä olet ja.

$45 \quad($.

46 PO: Nii.

47 AN: Kuinka sinä olet tyytyväinen kaikkeen mitä

48 tapahtuu.

$49 \quad()$

50 PO: mt Nii nii et et enhän minä semmosta niinkun

51 (.) pyhimystä yrittäny esittää (.) (hänelle).

$52 \quad($.

$53 \mathrm{AN}$ : .mthh Eli (.) mitä se tarkottaa se tarkottaa

54 että (.) sinä koko ajan pelkäät että minä ym-

55 märrän sinut väärin. .hhh ja nimenomaan

56 ilkeällä tavalla väärin.

57 PO: Ilkeälläh.

Potilas puhuu suhteestaan äitiinsä (rivit 1-19), ja analyytikko esittää tämän puheen varaan rakentuvan transferenssitulkinnan (tulkinnan joka sisältää viittauksen potilaan ja analyytikon suhteeseen): "Se on sama asia mitä sinä oot miettiny paljon täällä suhteessa minuun" (21-22) Tyypilliseen tapaan tulkinta hyödyntää potilaan omaa puhetta rinnastaen kaksi sinänsä erillistä asiaa (potilaan suhde äitiinsä vs. potilaan suhde analyytikkoonsa): kuvataan siis toisen representoivan 1. esittävän toista (ks. Peräkylä 2004).

Potilas esittää katkoisen korjauspyynnön, jolla merkitsee edeltävän vuoron odottamattomaksi ja kutsuu analyytikolta selvennystä (24). Analyytikko vastaa purkamalla tulkintansa perusteita: "Niin ku sinul on aina tarve - osottaa minulle et sinä olet hyvä" (26-27). Potilas vastaa puolustautuen sellaista implikaatiota vastaan, että hän ajattelisi itsestään liikoja (29-33). Samalla hän tulee torjuneeksi myös analyytikon varsinaisen tulkinnan, koska torjuu sen sisältämän rinnastuksen perusteet.

Analyytikko ei hyväksy selitystä eikä ala sen johdosta korjaamaan tulkintaansa. Sen sijaan hän käsitteleekin potilaan vuoroa tunteenilmauksena, nostaen pelon huomion kohteeksi: "Tuota se on 
jännä kuinka sinä pelkäät” (35-36). Väite on vahva ja varmaksi muotoiltu. Analyytikko ei vain esitä, että tunne on, vaan ikään kuin asettuu ihmettelemään sitä.

Potilas vastustaa analyytikon toteamusta ja palaa laajentamaan selostustaan äitisuhteestaan. Näin hän tulee vastustaneeksi myös analyytikon esittämää transferenssirinnastusta. Rivit 38-51 näyttävät jakson, jossa puhujat rakentavat yhteistyössä kuvauksen potilaan kokemuksesta - sellaisen jonka hän itse esittää oikeampana kuin analyytikon transferenssitulkinnan ilmentämä kuva. Pian analyytikko kuitenkin fokusoi uudelleen potilaan tunnetilaan: " Eli-mitä se tarkottaa se tarkottaa että - sinä koko ajan pelkäät että minä ymmärrän sinut väärin - ja nimenomaan ilkeällä tavalla väärin.” (53-56). Tämän tulkinnan resurssina on aiempi transferenssitulkinta, ja lisäksi se on muotoiltu päätelmäksi edeltävästä puheesta.

Potilaan selityksiä ei siis käsitellä autoritatiivisena kuvauksena hänen mielensä sisällöstä, vaan ne luetaan lisätodisteeksi siitä, että hän todellisuudessa pelkää - ja pelkää nimenomaan analyytikon arviota hänestä. Analyytikko siis käsittelee potilaan puhetta oman transferenssitulkintansa ja siihen liitetyn tunnekuvauksensa todistusaineistona.

Esimerkki 5 edustaa laajempaa kokoelmaa; ja se sisältää useita oleellisia piirteitä, jotka ovat yhteisiä kaikille analysoimilleni tunteentopikalisoinneille:

1) Analyytikko ottaa puheeksi tunteen vastauksena potilaan vuoroon.

2) Tunne on negatiivinen.

3) Analyytikon vuoro kutsuu potilaalta vastausta, tarkemmin sanottuna selontekoa, eli haastaa potilasta.

4) Ottamalla puheeksi tunteen analyytikko muuttaa keskustelun fokusta ja huolehtii samalla, että se pysyy potilaassa.

5) Tunteentopikalisoinnin välittömänä kontekstina on potilaan vastustus analyytikon agendaa kohtaan. Tässä yhteydessä tarkoitan potilaan esittämää tulkinnan torjuntaa (29-33), mutta kokoelmassani se voi olla myös mm. vapaasta assosioinnista pidättymistä tai analyytikon haastamista.

6) Siirtämällä huomion potilaan tunteeseen analyytikko välttää käsittelemästä niitä "velvoitteita" l. odotuksia, joita potilaan vuoro on hänen puheelleen luonut. Tässä tapauksessa hän siis si- vuuttaa sen, että potilas on torjunut omaa mieltään käsittelevän väitteen.

$\mathrm{E}$ dellisen nojalla näemme, mitä vuorovaikutuksellisia seuraamuksia potilaan tunteen puheeksi ottamisella on tässä institutionaalisessa ympäristössä. Se toimii analyytikon keinona ohittaa potilaan vastarinta niin, että analyytikon tulkinta tai näkökulma säilyy puheenalaisena. Lisäksi siirtämällä huomion potilaan tunteeseen (tai toisinaan muuhun havaittavaan käyttäytymiseen kuten puhetapaan tai toimintoon) analyytikko tekee jonkin seikan potilaan käyttäytymisessä huomionarvoiseksi, arvoitukselliseksi ja selitystä vaativaksi. Tällaisten "arvoitusten" esille nostaminen on havaitsemamme mukaan eräs oleellinen osa psykoanalyytikon työskentelyä, ja sen tuloksena syntyy vuorovaikutuksel-lisesti otollisia paikkoja psykoanalyyttisille tulkinnoille: väittämille joissa analyytikko ehdottaa potilaalle jotain hänen tiedostamattomansa sisällöstä. (Tulkinnan kategoriasta tutkimuksessamme Vehviläinen 2003, Peräkylä 2004; psykoanalyyttisista tulkinnan määritelmistä esim. Sandler et al. 1992, 155; Rycroft 1995; 85-86; Frosh 2003, 74-76.)

Ilmiö on kiistanalainen: sekvenssinhän voi lukea potilaan pussiin puhumisena. Psykoanalyyttisen työskentelyn ideana on nostaa esiin nimenomaan tiedostamatonta vastarintaa ja sitä kautta päästä kiinni oleellisiin syviin ristiriitoihin, joista paranemisen tai eheytymisen ajatellaan olevan kiinni (Ikonen 2000; Frosh 2003, 84-85). Näyttää siltä että on käytännössä vaikea identifioida tiedostamatonta vastarintaa joutumatta samalla tekemisiin vuorovaikutuksellisen vastarinnan ja usein lopulta haastavan ja väittelevän puheen kanssa.

Ajatus tiedostamattomasta ja sen kanssa työskentelystä muuttaa ratkaisevalla tavalla erästä perustavaa vuorovaikutusta jäsentävää periaatetta: ajatusta kokemuksen omistamisesta. Yleensä ajattelemme "omistavamme" kokemuksemme, mielemme sisällön ja siten olevamme omaa kokemustamme koskevissa asioissa "auktoriteetteja". Monet vuorovaikutuskäytänteet perustuvat tähän periaatteeseen (esim. Pomerantz 1980; Peräkylä 1995, 103-143). Psykoanalyysin keskustelukäytännöt sen sijaan perustuvat ajatukseen tiedostamattomasta, josta seuraa ettei kokemuksen omistajuus olekaan aukoton. Tunne voi tällöin toimia vuorovaikutuksellisena resurssina toi- 
sen mieltä ja "tiedostamatonta" koskevan näkemyksen rakentamisessa.

\section{MITÄ HALUAMME TIETÄÄ \\ TUNTEISTA JA \\ VUOROVAIKUTUKSESTA?}

Tunteisiin keskittyvä aikuiskasvatuksen vuorovaikutustutkimus kohtaa melko kartoittamattoman kentän. Edellä kuvasin joitakin mahdollisia analyyttisia lähtökohtia sekä tutkimustuloksiani:

(1) Kuvasin tunnelman rakentumista vuorovaikutuskäytänteiden aikaansaannoksena. Kyse oli yhdestä tilannetyypistä (psykodraama-työskentelyn jakaminen) ja yhdestä tunnetyypistä ("lämmin, harras tunnelma"), mutta molempien osalta asetelmaa voisi laajentaa.

(2) Kuvasin tunnetta moraalityön ja yhteisyyden resurssina tilanteessa, jossa vastaanotetaan ja tulkitaan toisten ihmisten henkilökohtaisia narratiiveja. Kokemusten reflektointiin perustuvat oppimistilanteet edellyttävät osallistujiltaan paitsi kielellisen osallistumisen monipuolisia taitoja, myös psykokulttuurista kompetenssia, ja sen erittely olisi mielestäni erityisen tärkeätä.

(3) Niissä käytännöissä, joissa käsitellään tiedostamatonta, negatiivista tunnetta voidaan vuorovaikutuksessa kohdella 'ikkunana' tiedostamattomaan. Kuvasin tunneviittauksen käyttöä erityisesti tilanteissa, joissa psykoanalyytikko nostaa esille ja käsittelee potilaan vastarintaa. Uskoakseni tunne voi toimia vastavassa roolissa monissa muissakin käytännöissä - vähemmän argumentatiivisissa tilanteissa. Tiedostamattoman kategoria jäsentää myös arki-psykologisia tai kvasipsykologisia käytäntöjä, joiden empiirisestä tutkimuksesta aikuiskasvatustiede voisi kiinnostua huomattavasti laajemminkin.

Kasvatuksen, koulutuksen, ohjauksen ja terapian käytäntöjä voisi tarkastella eräänlaisena jatkumona, jossa "tulkinnallisuus" on yksi jäsentävä ulottuvuus. Käytäntöjä voi vertailla sen mukaan, onko "tiedostamaton" käytännössä huomioonotettava resurssi vai ei, kuinka paljon asiakkaan kokemuksesta oletetaan ammattilaisen saataville ja päättelyn kohteeksi, kuuluko ammattilaisen "lukea" asiakkaan tunnetiloja ja ottaa nämä vuorovaikutuksessa huomioon vai ei (Vehviläinen 2001, 134-154; Hak \& DeBoer 1996).

Sitä mukaa kun aikuiskasvatuksen kentillä luovutaan formaalin tiedon korostamisesta ja rakennetaan oppimistilanteita kokemusten tai identi- teetin työstämisen varaan, on oletettavissa että aikuiskasvatuksen käytännöt ja vuorovaikutusmallit alkavat muistuttaa terapeuttisia työtapoja. Niissä siis puhutaan - kuten kuvaamissani tilanteissa - omista tunteista, käytetään tunnereaktioita 'todisteina' sekä yhteenkuuluvuuden 'valuuttana'. Niissä voidaan synnyttää myös vahvoja kollektiivisia tunteita tai tunnelmia. Niissä syntyy vaikutuksia, jotka eivät ole niinkään tiedollisia kuin emotionaalis-esteettisiä (vrt. Kellerman 1992, 90-95).

Kiinnostus tunteita kohtaan aikuiskasvatuksessa lienee osoitus tästä terapiaa lähenevästä kehityksestä. On myös mahdollista, että vuorovaikutuskäytännöt ja käytäntöjä suuntaavat teoriat tai ideologiat eivät muutu samassa tahdissa, vaan katkoksellisesti ja polveillen. Vuorovaikutustutkimus paljastaa usein seikkoja, joiden suhteen käytännöt ja ideologiat eivät kulje samaan tahtiin (vrt. Peräkylä \& Vehviläinen 2003). Tämän vuoksi tunnetyöskentelyn empiirinen tutkimus aikuiskasvatuksen vuorovaikutustilanteista olisi erityisen tärkeätä. Tunne voi olla aikuiskasvatuksessa sosiaalisen toiminnan resurssi mutta myös oppimisen substanssi - molempia näkökulmia tulisi tarkastella. Olisi hyvä että vältettäisiin tilanne, jonka olen aikanaan kokenut aloittelevana ohjaustyöläisenä - ja jonka olen tavannut myöhemmin myös toisten ohjaustyöläisten kuvauksista - että joutuu ajoittain tekemään psykologityötä ilman psykologityön välineitä.

\section{VIITTEET}

1 Tunteet voidaan tietysti ymmärtää oppimisen ja kasvatuksen kannalta myös substanssina, tarkastelun, oppimisen ja ymmärtämisen kohteena. Terapiakäytännöissä tämä on vielä keskeisempi näkökulma. Tarkastelussani keskityn kuitenkin tunteisiin nimenomaan vuorovaikutuksen resurssina.

2 Tämän lisäksi on paljon sellaista nonverbaalia viestintää joka osaltaan kannattelee (tai häiritsee, tekee tyhjäksi) tilanteen tunnelmaa: kasvojen eläminen ajatusten ja keskustelujen mukana, asennot, hymyt, katseet, kulmien kohotukset. Tällä aineistolla en kuitenkaan pääse sellaiseen viestintään käsiksi. Tunnelman yksilöt rakentavat osana kollektiivia, ja yksittäinen nonverbaali häiritsijä ei vielä tee tyhjäksi tilanteen luonnetta. Kuinka moni voisi - se olisi jo toisen tutkimuksen aihe. 


\section{Liite: Transkriptiokoodien selitykset}

(vrt. Seppänen 1997)

Psykodraama-aineisto:

() yli sekunnin tauko

(.) lyhyt tauko

(()) litteroijan huomioita

[ ] päällekkäispuhunta

ei painotus

(- -) epäselvä sana

(- - -) useita epäselviä sanoja

Psykoanalyysiaineistossa lisäksi:

AN: psykoanalyytikko

PO: potilas

. laskeva vuoronloppuinen intonaatio

, tasainen intonaatio

.hh sisäänhengitys

mit- katkaistu sana

\section{KIRJALLISUUS}

Arminen, I. (1998). Therapeutic interaction. A study of mutual help in Alcoholics Anonymous. The Finnish Foundation of Alcohol Studies.

Bamberg, M. (1997). Emotion talk(s): The role of perspective in the construction of emotions. Teoksessa Niemeier, S. \& Dirven, R. (toim.) The Language of Emotions. Conceptualization, expression, and theoretical foundation. Amsterdam: John Benjamins.

Berscheid, E. (1990). Contemporary vocabularies of emotion. Teoksessa Moore, B. \& Isen, A. M. (toim.) Affect and social behaviour. Cambridge University Press.

Besnier, N. (1990). Language and affect. Annual Review of Anthropology, 19, 419-451.

Coulter, J. (1979). The Social Construction of Mind. London: Macmillan.

Drew, P. \& Heritage, J. 1992. Talk at Work. Interaction in Institutional Settings. Cambridge University Press

Edwards, D. 1999. Emotion discourse. Culture and Psychology, 5 (3), 271-291.

Edwards,D. \& Potter, J. (1992). Discursive Psychology. London: Sage.

Forsberg, H. (2002).Tunteet - sosiaalityötä harjoittelevan häpeä? Aikuiskasvatus 4, 295-305.

Furedi, F. (2004). Therapy Culture.Cultivating vulnerability in an uncertain age. Routledge.

Frijda, N. H. (2000). The Psychologists' Point of View. Teoksessa Lewis, M. \& Haviland-Jo- nes, J.M. (toim.) Handbook of Emotions. 2nd Edition. New York: The Guildford Press, s.59-74 Garfinkel, H. (1967). Studies in Ethnomethodo$\operatorname{logy}$. Englewood Cliffs, NJ: Prentice-Hall.

Giddens, A. (1991). Modernity and Self-identity. Self and Society in the Late Modern Age. London: Polity Press.

Goddard, C. \& Wiertzbicka, A. (1997). Discourse and Culture. In Dijk, T. van (toim.) Discourse as Social Interaction. Discourse Studies: A Mul-tidisciplinary Introduction. Vol. 2. SAGE. Goffman, E., (1981). Forms of talk. University of Pennsylvania Press.

Goffman, E. (1986). Frame Analysis. Chicago: Aldine.

Hak, T. \& DeBoer, F. (1996). Formulations in first encounters. Journal of Pragmatics 25, 83B99.

Hakulinen, A. 1997. Vuorottelujäsennys. Teoksessa Tainio, L. (toim.) Keskustelunanalyysin perusteet. Vastapaino.

Halonen, M. (1999). Vuorottelujäsennys ryhmä-terapiassa. Virittäjä 3: 338B353.

Harre, R. and Parrott, W.G. (toim.1996). The Emotions. Social, Cultural and Biological Dimensions. London: Sage.

Heiskala, R. (1991). Goffmanista semioottiseen sosiologiaan. Sosiologia 2, 90-107.

Heritage, J. (1996). Garfinkel ja etnometodologia. Gaudeamus.

Heritage, J. \& Atkinson, J.M. (1984). Introduction. Teoksessa Atkinson, J.M. \& Heritage, J. (toim.) Structures of social action. Cambridge University Press.

Hester, S. \& P. Eglin (toim.1997). Culture in Action. Studies in Membership Categorization Analysis. Lanham: University Press of America \& International Institute for Ethnomethdology and Conversation Analysis.

Ikonen, P. (2000). Psykoanalyyttisia tutkielmia. Nuorisopsykoterapia-säätiö.

Isokorpi, T. (2003). Tunneälytaitojen ja yhteisöllisyyden oppiminen kokemuksen reflektoinnin ja ryhmäprosessin avulla. Hämeenlinnan ammattikorkeakoulu.

Kellerman, P.F. (1992). Focus on Psychodrama. The Therapentic Aspects of Psychodrama. London: Jessica Kingsley.

Lasch, C. (1980). The culture of narcissism. 
American life in an age of diminishing expectations. Abacus.

Moreno, J. L. (1977). Psychodrama. New York: Beacon House.

Nussbaum M. (2003). Upheavals of thought. The Intelligence of Emotions. Cambridge University Press.

Ochs, E. \& Schieffelin, B.B. (1989). Language has a heart. Text, 9, 7-25.

Lahti, R. (2001). Ammatinvalinnanohjaajien vastauksia asiakkaiden tiedostamattomiin odotuksiin. Transferenssi-ilmiöiden merkitys ohjauksen vuorovaikutuksen ja tulosten näkökulmasta. Työpoliittinen tutkimus 22. Työministeriö. Peräkylä, A. (1990). Kuoleman monet kasvot. Identiteettien tuottaminen kuolevan potilaan hoidossa. Vastapaino.

Peräkylä, A. (1995). Aids counselling. Institutional interaction and clinical practice. Cambridge University Press.

Peräkylä, A. (2004) Two traditions of interaction research. British Journal of Social Psychology 43, 1-20.

Peräkylä, A. (2004). (tulossa) Making links in psychoanalytic interpretations: a conversation analytic view. Psychotherapy Research 14.

Peräkylä, A \& Vehviläinen, S. (2003). Conversation analysis and the professional stocks of interactional knowledge. Discourse in Society 14 (6), 727-750.

Planalp, S. (1999). Communicating Emotion : Social, Moral, and Cultural Processes. Cambridge University Press

Rycroft, C. 1995 (1968). A critical dictionary of psychoanalysis. London: Penguin.

Sacks, H. 1995. Lectures in conversation. Vol I \& II. Toimittanut Gail Jefferson. Oxf: Blackwell. Sacks, H.; Schegloff, E.A. \& Jefferson, G. (1974). A simplest systematics for the organization of turn-taking in conversation. Language 50, 696-735. Sandler, J., Dare, C. \& Holder, A. (1992). The Patient and the Analyst. The Basis of the Psychoanalytic Process. London: Karnac.

Sennett, R. (1986). The fall of the the public man. Faber and Faber.

Seppänen, E-L. (1997). Keskustelu paperilla. Teoksessa Tainio, L. (toim.) Keskustelunanalyysin perusteet. Vastapaino.
Schwartz, H. (1989). The life history of a social norm. Teoksessa Helm, D.T. \& Anderson, W.T. \& Meehan, A.J. \& Warfield, A. (toim.) The Interactional Order. New Directions in the Study of Social Order. New York: Irvington.

Silvennoinen, P. (2002). Ikääntyvät pitkäaikaistyöttömät ja ohjaava koulutus. Aikuiskasvatus 2, 124-133.

Taylor, C. (1995). Autenttisuuden etiikka. Gaudeamus

Varila, J. (1999). Tunteet ja aikuisdidaktiikka. Tunteiden aikuisdidaktisen merkityksen teoreettinen ja empiirinen jäsennys. Joensuun yliopisto, Kasvatustieteiden tiedekunnan tutkimuksia 74.

Varila, J. \& Ikonen-Varila, M. (2002). Ylpeys ja ammattiylpeys tutkimuksen kohteeksi. Ylpeyden tunteen teoreettinen ja empiirinen tarkastelu. Joensuun yliopiston kasvatustieteen tiedekunnan julkaisuja.

Vehviläinen, S. (1996a). Psykodraaman vuorovaikutuksen rakentuminen. Etnometodologinen tarkastelu. Helsingin yliopisto, Kasvatustieteen laitos, Tutkimuksia 148.

Vehviläinen, S. (1996b). Osallistujakehys psykodraaman vuorovaikutuksessa: etnometodologinen tarkastelu. Sosiologia 2, 103-113.

Vehviläinen, S. (1997). Aikuiskasvatus ja integroidut koodit: Ohjaava koulutus avoimena pedagogiikkana. Aikuiskasvatus 3.

Vehviläinen, S. (2001). Ohjaus vuorovaikutuksena. Gaudeamus.

Vehviläinen. S. (2002). Potilaan välittömän tunteen topikalisointi psykoanalyysivuorovaikutuksessa. Teoksessa Mauranen, A. \& Tiittula, L. (toim.) Kieli yhteiskunnassa - yhteis-kunta kielessä. AFinLan vuosikirja n:o 60 Jyväskylä: Suomen soveltavan kielitieteen yhdistys.

Vehviläinen, S. (2003). Preparing and delivering interpretations in psychoanalytic interaction. TEXT 23 (4): 573B606.

White, G.M. (2000). Representing Emotional Meaning: Category, Metaphor,Schema, Discourse. Teoksessa Lewis, M. \& Haviland-Jones, J.M. (toim.) Handbook of Emotions. 2nd Ed. New York: The Guildford Press, s. 30-44 